\title{
Drying time and post-harvest quality of onion bulbs submitted to artificial curing
}

\author{
Deise Silva Castro Pimentel Cardoso ${ }^{1 *}$, Ariana Mota Pereira ${ }^{1}$, Teresa Drummond Correia ${ }^{1}$, Fernando Luiz Finger ${ }^{1}$
}

$10.1590 / 0034-737 X 201663060011$

\begin{abstract}
After harvest, onion bulbs are submitted to curing, whose objective is to provide loss of moisture in leaves and drying of outer layers (peel) of bulbs, reaching attractive external coloration and reduction in the intensity of rottenness. The objective of this study was to use an air treatment unit (ATU) - known as heat pump - as an alternative drying method, and to evaluate drying time and preservation of the chemical and physical characteristics. The experiment was carried out in a complete random design with ten replicates and three treatments, which were the following: $\mathrm{T}_{1-}$ (control) natural curing in shed; (2) $\mathrm{T}_{2-}$ (aeration with air artificially heated by propane burning); and (3) $\mathrm{T}_{3-}$ (aeration with artificially dehydrated and heated air using ATU). Curing completion time, relative water content (RWC) of the skin and inner layers, pulp color and skin coloring, total titratable acidity (TTA), total soluble solids (TSS), visual index of dormancy breaking (VID), and fresh weight loss (FWL) were evaluated in this study. No significant difference ( $\mathrm{p}<$ 0.05 ) were found for TTA, TSS, VID, FWL, and pulp color among treatments. It can be concluded that $\mathrm{T}_{3}$ promoted a faster curing (12 hours) of bulbs, which provided bulbs with drier skin and intense yellow color.
\end{abstract}

Key words: Allium cepa; chemical and physical characteristics; drying methods; heated air.

\section{RESUMO}

\section{Tempo de secagem e qualidade pós-colheita de bulbos de cebola submetidos à cura artificial}

Após a colheita da cebola, realiza-se a cura cuja finalidade é proporcionar a perda da umidade das folhas e secagem das películas externas (casca) dos bulbos, alcançando coloração externa atrativa e redução da intensidade de podridões. Objetivou-se com este trabalho utilizar uma unidade de tratamento de ar (UTA), conhecida como bomba de calor, como método alternativo de secagem e avaliar o tempo de secagem e a preservação das características químicas e físicas dos bulbos de cebola após a cura. O experimento foi conduzido no delineamento inteiramente casualizado com dez repetições e três tratamentos que consistiram em: $T_{1}$ - (Testemunha) cura natural realizada em galpão. $T_{2}$ - (aeração com ar aquecido artificialmente pela queima de propano) e $\mathrm{T}_{3}$ - (aeração com ar aquecido e desidratado artificialmente por meio da UTA). Avaliou-se o tempo de finalização da cura, teor relativo de água (TRA) da casca e películas internas, coloração da casca e polpa, acidez total titulável (ATT), sólidos solúveis totais (SST), índice visual de superação da dormência (IVD) e perda de massa fresca (PMF). Não houve diferença significativa ( $\mathrm{p}<0,05)$ para a ATT, SST, IVD, PMF e coloração da polpa entre os tratamentos estudados. Conclui-se que o $\mathrm{T}_{3}$ permitiu a cura dos bulbos de forma mais rápida (12 horas), proporcionando bulbos com casca mais seca e coloração amarelo intenso.

Palavras-chave: Allium cepa; características químicas e físicas; métodos de secagem; ar aquecido.

\footnotetext{
Submitted on January $19^{\text {th }}, 2015$ and accepted on August $05^{\text {th }}, 2016$.

${ }^{1}$ Universidade Federal de Viçosa, Departamento de Fitotecnia, Viçosa, Minas Gerais, Brazil. deiselpimentel@yahoo.com.br; ariana.mota@ufv.br; tdcorreia1@yahoo.com.br; ffinger@ufv.br *Corresponding author: deise1pimentel@yahoo.com.br
} 


\section{INTRODUCTION}

In Brazil, onion, together with potatoes and tomatoes, are the most economically important vegetable crop, both for volume production and the generated income. Brazilian production reached 1.65 million tons in an area of approximately 57,800 hectares in 2014 (IBGE, 2015).

Curing is one of the main processes that determine the maintenance of the quality, aiming at reducing moisture after harvest, which allows the change of skin color, production of volatile sulfurate compounds that enhance the aroma, reduction in the susceptibility of the bulbs to penetration by microorganisms, which are characteristics that change according to the genotype (Finger \& Casali, 2002). It can be carried out naturally or artificially. Natural curing is done in the field, for a period of three to ten days, depending on weather conditions. At harvest, farmers leave the bulbs on the ground, piled in rows, so the leaves of the onions cover the others, protecting them from direct sunlight, thus preventing the development of green pigmentation and burns. After curing on fields, they are carried to the completion of the curing that is completed in a few weeks (Boeing, 2002).

Artificial curing may be an alternative in regions where weather conditions do not allow the process to be carried out in a natural way, mainly due to rainfall and periods of low temperatures associated with cloudiness. In this case, fans with natural or heated air are used. (Cardoso, 2012). According to Matos (1987), the forced circulation of heated air over the bulbs is a rational, efficient and economic method of artificial curing, however, low availability of information for this method was found. Most of the consulted literature is old with insufficient data.

The use of an air treatment unit (ATU), known as heat pump for drying agricultural products can be a rational option of artificial curing. The equipment removes moisture from air by cooling and condensing the water vapor present in the air, with subsequent heating to obtain air with a lower humidity. Thus, water retention capacity increases and air mixing ratio decreases, resulting in drier air (Santos, 2007). In addition, the equipment presents low power consumption (electricity), consuming between 60 to $80 \%$ less energy than conventional dryers when operating at the same temperature (Schmidt et al., 1998; Strommen et al. 2002). This makes those dryers a viable option for users who are not satisfied with the high power consumption of conventional dryer.

The objective of this work was to use an air treatment unit (ATU), known as heat pump as an alternative method of drying and evaluating the drying time and the preservation of chemical and physical characteristics of onion bulbs.

\section{MATERIAL AND METHODS}

The experiment was carried out in Laboratório de PósColheita (Post-Harvest Laboratory) in the Plant Science Department in the pre-processing and storage area of plant products in the Departamento de Engenharia Agrícola (Agricultural Engineering Department) at the Federal University of Viçosa, in October of 2011.

It was used 1,500 kg of "Bola Precoce" onion bulbs from small farmers in the rural region of Guiricema, state of Minas Gerais. Harvest was performed when $70 \%$ of the bulbs had fallen or cracked due to withering of pseudostem. After harvest, toilet (removal of roots close to the bulbs and leaves at three centimeters from pseudostem height) was carried out.

The treatments were, as follows: 11 - (Control) $500 \mathrm{~kg}$ of onions were arranged in suspended yards placed in a covered area in the pre-processing and storage of plant products sector at the Department of Agricultural Engineering. The average room temperature and air relative humidity were $23.3{ }^{\circ} \mathrm{C}$ and $79 \%$ respectively. T2 (artificially heated air) $500 \mathrm{~kg}$ of onion were placed in a vertical silo with $1.0 \mathrm{~m}$ of diameter and $1.5 \mathrm{~m}$ in height. The air was heated by propane burning conducted by a 1.5 $\mathrm{kW}$ axial triphase power fan positioned at the silo entrance, with average drying temperature and air relative humidity of $36^{\circ} \mathrm{C}$ and $47.9 \%$ respectively. The air flow was $0.4 \mathrm{~m}^{3}$ $\min ^{-1} \mathrm{t}^{-1} . \mathrm{T}^{3-}$ (artificially heated and dried air); $500 \mathrm{~kg}$ of onion were placed in a vertical silo with $1.0 \mathrm{~m}$ of diameter and $1.5 \mathrm{~m}$ in height. The air was heated and dried artificially by means of an air treatment unit (ATU - heat pump) developed by Cool Seed Indútria e Comércio de Aeração Condicionada Ltda ${ }^{\circledR}$. Average temperatures and relative humidity of the drying air was $33{ }^{\circ} \mathrm{C}$ and $40.3 \%$ respectively. The air flow was $0.4 \mathrm{~m}^{3} \mathrm{~min}^{-1} \mathrm{t}^{-1}$. The experiment was conducted in a complete random design with ten replicates.

The experiment evaluated the time necessary for curing completion, relative water content (RWC) of the skin and inner layer, skin and pulp color, total titratable acidity, total soluble solids, visual index of dormancy breaking and loss of fresh mass.

Curing cycles were performed until complete drying of the "neck" (pseudostem) of bulbs, which was determined by the visual lack of moisture by pressing the bulbs with the fingers. Each cycle corresponded to the period of hours during which the equipment were on.

To determine water content in the skin and inner layers, color of skin and pulp, total titratable acidity, total soluble solids and visual index of dormancy breaking, samples were taken at time zero and at the end of the curing process of each treatment. 
Relative water content was determined according to Catsky's methodology (1974), by adapting the methodology for determining the time of maximum saturation of the tissue. Ten disks of skin and inner layer with $11 \mathrm{~mm}$ diameter were removed with the aid of a metal punch when mass of fresh matter was determined; then the disks were placed on foam moistened with distilled water, where they remained for six hours to reach maximum saturation. The mass was considered mass of turgid matter. Then, the disks were dried in an oven at a temperature of $65{ }^{\circ} \mathrm{C}$ until constant weight, to obtain the dry matter. Relative water content (RWC) was obtained using the equation of Weatherley (1950):

$\mathrm{RWC}=100(\mathrm{FM}-\mathrm{DM}) /(\mathrm{TM}-\mathrm{DM})$

Where:

FM is fresh matter mass $(\mathrm{g})$;

DM is dry matter mass $(\mathrm{g})$; and

TM is the turgid matter $(\mathrm{g})$.

Color quantification was carried out by direct reading of reflectance of coordinates "L", "a" and "b" using colorimeter Colortec - PCM, Minolta ${ }^{\circledR}$. For each repetition of all the evaluated treatments, the average of three readings per sample was used. The value "L" expresses the brightness and the closer to 100 , the clearer the product. The values of "a" indicate the tendency to color, which ranges from green (negative values) to red (positive values +); however, the values of "b", tend from blue (negative values -) to yellow (positive values + ). From the values of "a" and "b", it was calculated saturation $(\mathrm{C})$, which measures color intensity and the angle of hue $(\theta)$, which indicates the chromatic shade (attribute at which color is perceived) by the equations:

$C=\left(a^{2}+b^{2}\right)^{1 / 2}$

$(\theta)=\operatorname{arctg}(\mathrm{b} / \mathrm{a})$

(Little, 1975).

Titratable Acidity (TA) was carried out by titration of $10 \mathrm{~g}$ of ground onion in $50 \mathrm{ml}$ of distilled water with a $\mathrm{NaOH} 0.1 \mathrm{~N}$ standard to reach $\mathrm{pH}$ 8.2. Titrable acidity was expressed as percentage of citric acid.

The percentage of soluble solids (Brix) was determined in samples taken from the ground pulp and quantified in digital refractometer.

The visual index of dormancy breaking (DVI) was determined by longitudinal cuts on insertion of bulbs, where length of the shooting leaf and the total longitudinal length of the bulb were measured (Muller, 1982). Length was measured with a ruler and expressed in centimeters $(\mathrm{cm})$. The visual index of dormancy breaking was expressed as a percentage $(\%)$ and determined from the equation:
$\operatorname{IVD}(\%)=\mathrm{LL} / \mathrm{CL} \times 100$

Where:

LL: length of shooting leaf and

CL: total length of the bulb.

The percentage of weight loss of fresh mass was estimated every three hours during the first twelve hours, with the equipment on. From that point, it was estimated every 12 hours until curing completion of all treatments. To estimate the loss of fresh mass, silos were stratified into three layers: lower (corresponded to the base of the silo), medium (corresponded to the middle of the silo) and higher (corresponded to the top of the silo).

The results were expressed in percentage of accumulated mass loss of fresh matter according to the following equation:

$\mathrm{FML}=100-\left(\left(\mathrm{PF}^{*} 100\right) / \mathrm{PI}\right)$

Where:

$\mathrm{FML}=$ fresh matter loss $(\%)$

$\mathrm{FW}=$ final fresh matter weight $(\mathrm{g})$ on the analysis day; and

IW = initial weight of the fresh matter $(\mathrm{g})$, at the moment of the experiment setting up.

Data were submitted to analysis of variance and means were compared by the test of Tukey with $p<0.05$.

\section{RESULTS AND DISCUSSION}

Treatment T1 (control) finished curing after 168 hours at room temperature and relative humidity, which was approximately $24.5^{\circ} \mathrm{C}$ and $80 \%$ respectively. While in T2 (aeration with heated air), curing of the bulbs was completed at 27 hours, with a 12-hour cycle and another 3 -hour cycle (15 hours with the equipment on plus 12 hours with equipment off). In T3 (with heated and dehydrated air), curing was performed with only a 12-hour cycle, or 12 hours with the equipment on, which was the treatment that allowed performing curing in the shortest period of time (Figure 1).

At the end of onion curing, average relative water content of the skin was lower in treatments T2 and T3 in relation to the control, indicating that curing using heated air either by propane burning or by UTA, was more effective in promoting dehydration of onion (Figure 2).

The average value of relative water content of the inner layer in $\mathrm{T}_{3}$ (heated and dehydrated air) was higher than that of $\mathrm{T}_{1}$ and $\mathrm{T}_{2}$ (Figure 2). $\mathrm{T}_{3}$ allowed a faster onion bulb curing and with less reduction in internal water content, contributing to the maintenance of quality. In the other treatments, curing was performed more slowly, with a consequent higher water loss in the inner layers, thereby 
reducing the values of the TRA. Bulb drying occurs from the outer part towards the inner part, as the first layers get dryer, the flow of water occurs from the inner layers to the outer ones. The fastest drying of external layers in T3 promoted a more effective barrier against water loss in the inner layers.

No significant difference was found between treatments for the parameters "L", "a", "b", angle of hue $(\theta)$ and Chroma in relation to the pulp color. No significant difference was found between the chromaticity and treatments either, due to the uniformity of the batch used.
When parameter "b" was determined in the skin, $\mathrm{T}_{3}$ presented the lowest means, that is, lighter yellow bulbs than in the other treatments (Table 1).

The highest " $a$ " values of bulbs in $\mathrm{T}_{3}$ treatment bulbs in relation to the other treatments indicate that the bulbs cured with heated and dehydrated air had less greenish color. No statistical difference was found between treatments for the angle of hue.

No statistical difference was found in the skin brightness among treatments. No drying model promoted darkening of bulbs. Yokomizo et al. (1977) observed a

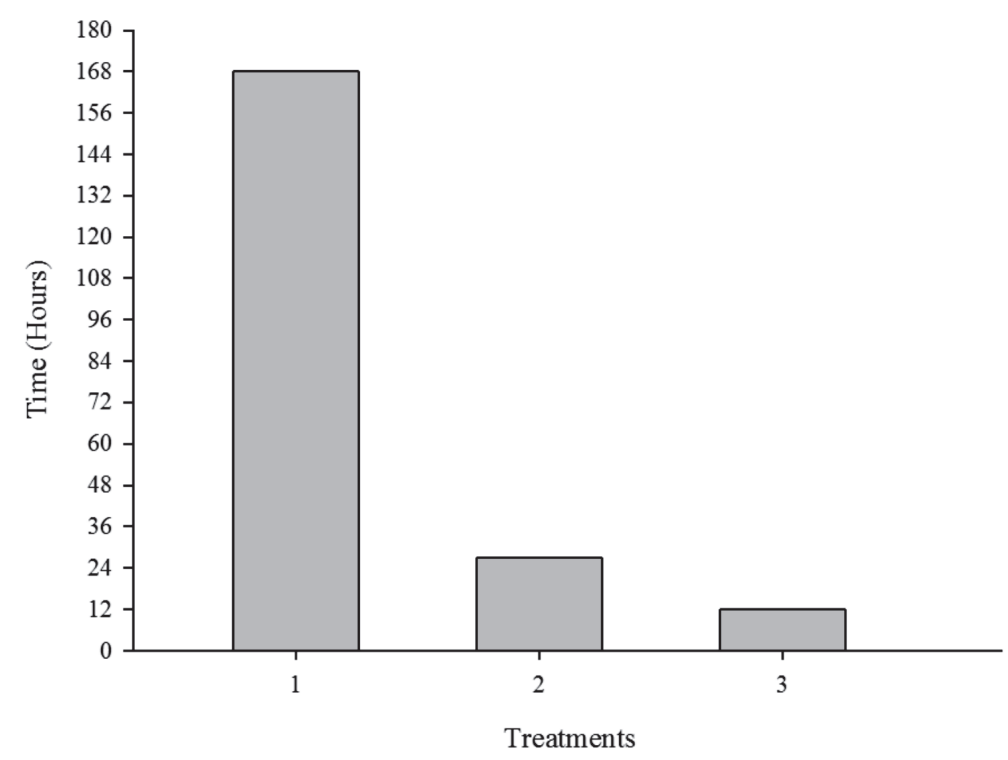

Figure 1: Drying time during artificial Bola Precoce onion bulbs curing for treatments: $T_{1}-$ Control; $T_{2}-$ heated air aeration and $T_{3}$ - heated and dehydrated aeration air.

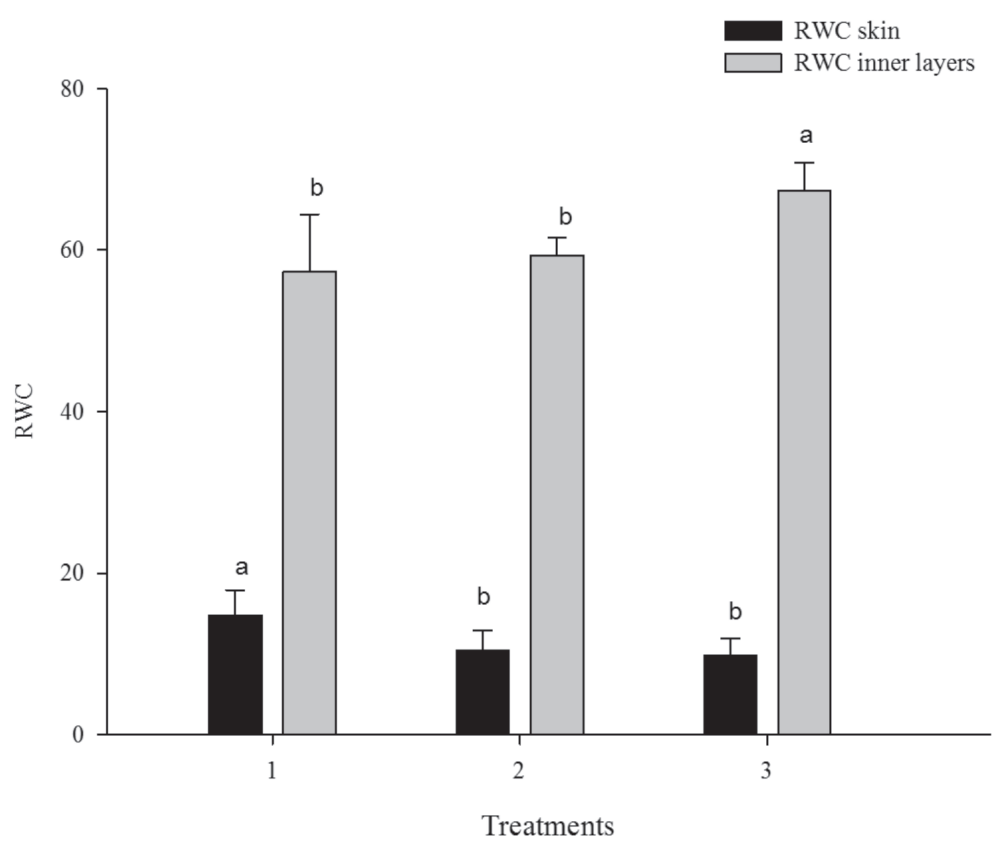

Figure 2: Relative water content (RWC) in the inner layer and skin of Bola Precoce onion bulbs for treatments: $\mathrm{T}_{1}-\mathrm{Control} \mathrm{T}_{2}-$ heated air aeration and $\mathrm{T}_{3}$ - heated and dehydrated air aeration. Vertical bars are the mean standard error. Bars followed by the same letter are not statistically different from each other by the test of Tuckey at $5 \%$ of probability. 
reduction in brightness or light darkening in experiments carried out with the variety "Baia Periforme". The darkening of the bulbs is due to the natural aging process and to the occurrence of spoilage pathogens. The bulbs presenting the best quality are those that remain with lighter color for a longer period of time (Pereira et al. 2012).

Parameter C (Chroma) defines the intensity of color, taking values close to zero for neutral colors and around 60 for bright colors (Mcguire, 1992). When we evaluated this parameter for the skin of the bulbs, treatment T3 promoted increase in this variable, indicating a more intensely colored skin than that of other treatments. Some authors indicate the preference of the market for more bulbs presenting intense yellow color (Souza et al., 2010). Miguel et al. (2005) worked with the curing of onion bulbs, Superex hybrid and also found that the bulbs cured at 20 ${ }^{\circ} \mathrm{C}$ became yellower.
No significant difference was found in the loss of fresh mass among the studied treatments. $T_{1}$ showed linear adjustment while the other treatments, regardless of the layer from where bulbs were removed, the adjusted model equation was the square root (Table 2). The average fresh weight loss in treatments was $1 \%$ at the end of the cure. In addition, a trend of a higher loss of fresh matter was found in the beginning of the curing than in the end.

Fresh mass loss of vegetables in post-harvest is affected by changes in temperature, storage air humidity and speed of air surrounding the product (Thompson, 1998). Changes in temperature values influence the respiratory rate and transpiration of those products. Onion respiration is regarded very low compared with other vegetables and it can be observed immediately after the completion of curing, but it significantly increases with storage time (Finger \& Casali, 2002). Onions were not

Table 1: Average values of "L", "a" and "b", hue and Chroma of pulp and skin of the Bola Precoce onion after curing for treatments: $\mathrm{T}_{1}-$ Control; $\mathrm{T}_{2}$ - aeration with heated air and $\mathrm{T}_{3}$ - aeration with heated and dehydrated air

\begin{tabular}{lccccc}
\hline \multirow{2}{*}{ Treatments } & \multicolumn{5}{c}{ Pulp color parameter } \\
\cline { 2 - 6 } & $\mathbf{L}$ & $\mathbf{a}$ & $\mathbf{b}$ & $\boldsymbol{\theta}$ & Chroma \\
\hline 1 & $61.36 \mathrm{a}$ & $8.77 \mathrm{a}$ & $33.87 \mathrm{a}$ & $1.32 \mathrm{a}$ & $8.170 \mathrm{E}-04 \mathrm{a}$ \\
2 & $64.83 \mathrm{a}$ & $4.38 \mathrm{a}$ & $31.58 \mathrm{a}$ & $1.43 \mathrm{a}$ & $9.841 \mathrm{E}-04 \mathrm{a}$ \\
3 & $63.33 \mathrm{a}$ & $5.75 \mathrm{a}$ & $33.77 \mathrm{a}$ & $1.40 \mathrm{a}$ & $8.522 \mathrm{E}-04 \mathrm{a}$ \\
\hline \multirow{2}{*}{ Treatments } & $\mathbf{L}$ & $\mathbf{9}$ & $\mathbf{b}$ & $\boldsymbol{\theta}$ & Chroma \\
\cline { 2 - 6 } & $67.26 \mathrm{a}$ & $-2.32 \mathrm{a}$ & $16.18 \mathrm{a}$ & $-1.43 \mathrm{a}$ & $3.743 \mathrm{E}-03 \mathrm{~b}$ \\
1 & $69.10 \mathrm{a}$ & $-2.05 \mathrm{a}$ & $15.47 \mathrm{a}$ & $-1.44 \mathrm{a}$ & $4.106 \mathrm{E}-03 \mathrm{~b}$ \\
3 & $67.52 \mathrm{a}$ & $-1.76 \mathrm{~b}$ & $15.32 \mathrm{~b}$ & $-1.46 \mathrm{a}$ & $4.205 \mathrm{E}-03 \mathrm{a}$ \\
\hline
\end{tabular}

* Means followed by the same letter do not differ from each other by the test of Tuckey at $5 \%$ of probability.

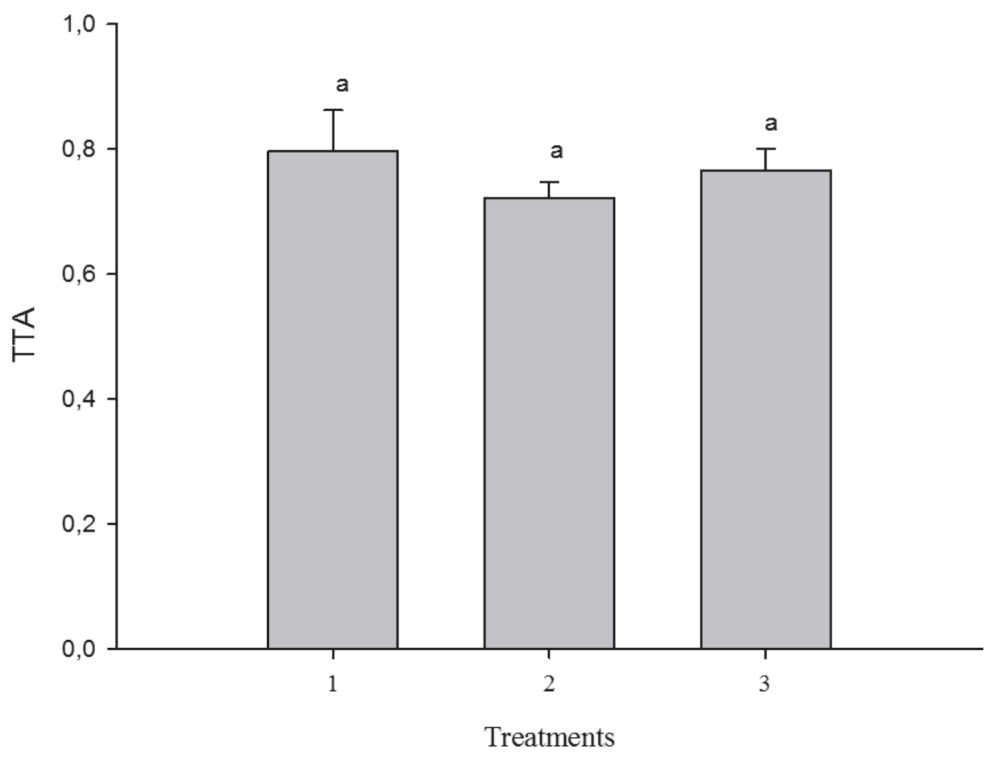

Figure 3: Total titratable acidity after Bola Precoce onion bulb curing for treatments: $\mathrm{T}_{1}-$ Control; $\mathrm{T}_{2}-\operatorname{artificial}$ heated air and $\mathrm{T}_{3}$ - heated and dehydrated air. Vertical bars are the mean standard error. Bars followed by the same letter are not statistically different from each other by the test f Tuckey at $5 \%$ of probability. 
stored after curing in this work. A small percentage of fresh mass loss observed in treatments is likely to have occurred because of the loss of moisture through transpiration.

Total titratable acidity and the percentage of total soluble solids (Brix) were not influenced by curing treatments (Figures 3 and 4). Total titratable acidity and total soluble solids contents are characteristic of each cultivar, therefore, the type of curing interferes very little in these characteristics (Grangeiro et al., 2008).

According to Maia et al (2000), the capacity of the onion to present few changes in its physical and chemical characteristics during storage can determine its commercial potential and acceptability, which allows minimizing post-harvest losses. Those same authors, when stored half-siblings progenies of multiple onions, found that the fresh weight of bulbs decreased over storage period and that during that period, dry matter and total soluble solids had increased. The visual index of breaking dormancy (IVD) was not influenced by the evaluated treatments (Figure 5). Because pseudostem is dehydrated, an intense activity of sprouting inhibitors occurs, causing the bulbs to remain dormant for a particular period of time. Dormancy is an important factor of

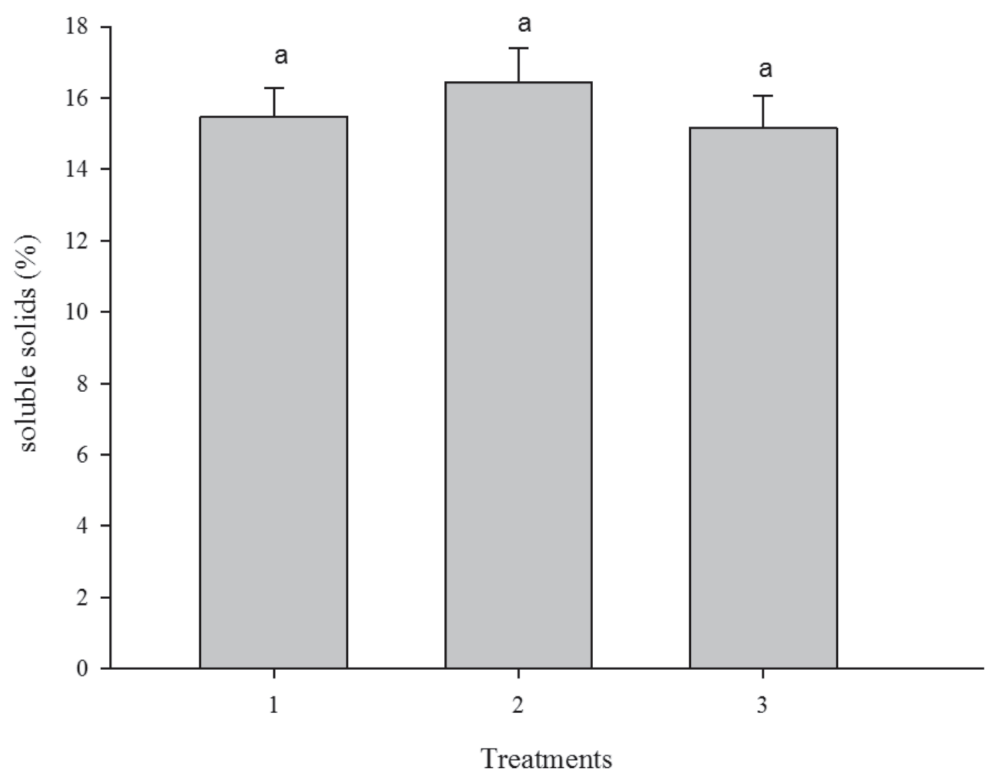

Figure 4: Total soluble solids after Bola Precoce onion bulbs for treatments: $T_{1}-$ Control; $T_{2}-$ heated air artificial aeration and $T_{3}$ -heated and dehydrated air aeration. Vertical bars are the mean standard error. Bars followed by the same letter are not statistically different from each other by the test of Tuckey at $5 \%$ of probability.

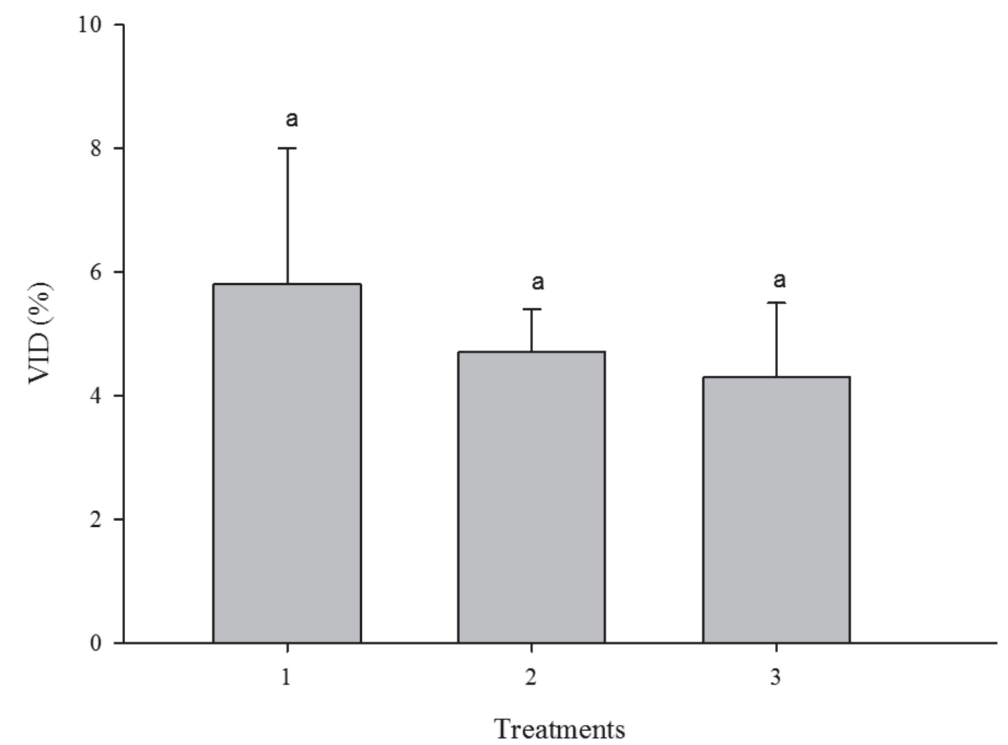

Figure 5: Visual index of dormancy breaking after Bola Precoce onion bulb curing for treatments: $\mathrm{T}_{1}-$ Control; $\mathrm{T}_{2}-$ artificial heated air and $\mathrm{T}_{3}$ - heated and dehydrated air. Vertical bars are the mean standard error. Bars followed by the same letter are not statistically different from each other by the test of Tuckey at $5 \%$ of probability. 
Table 2: Regression equations adjusted for percentage of relative fresh mass loss of Bola Precoce onion bulbs, obtained during curing for treatments: $\mathrm{T}_{1}-$ Control; $\mathrm{T}_{2}-$ heated air and $\mathrm{T}_{3}-$ dehydrated and heated air

\begin{tabular}{llll}
\hline Treatment & Position in the silos & Adjusted equations & $\mathbf{r}^{2} / \mathbf{R}^{\mathbf{2}}$ \\
\hline 1 & & $\hat{y}=0.01563 \mathrm{H}$ & 0.86 \\
2 & Bottom & $\hat{y}=0.27782$ “ $\mathrm{H}-0.00024 \mathrm{H}$ & 0.93 \\
Middle & $\hat{y}=0.48226$ "H-0.0014 H & 0.98 \\
& Top & $\hat{y}=0.23959$ "H-0.0014 H & 0.92 \\
3 & Bottom & $\hat{y}=0.38938$ "H-0.03140 H & 0.99 \\
& Middle & $\hat{y}=0.0100$ "H-0.0001 H & 0.97 \\
& Top & $\hat{y}=0.31535$ "H-0.00031 H & 0.79 \\
\hline
\end{tabular}

storage capacity of the bulb, and it can be described as the absence of growth of sprouting leaf, characterized by stretching of the sheath and the leaf blade (Bufler, 2001).

\section{CONCLUSION}

Treatment $\mathrm{T}_{3}$ (use of heated and dehydrated air through an air treatment unit) of the bulbs allowed a more rapid curing (12 hours), providing bulbs with drier skin and intense yellow color.

\section{ACKNOWLEDGMENTS}

The authors thank Conselho Nacional de Desenvolvimento Científico e Tecnológico - CNPq (National Council for Scientific and Technological Development ) for granting Master's degree scholarship.

\section{REFERENCES}

Boeing G (2002) Fatores que afetam a qualidade da cebola na agricultura familiar catarinense. Florianópolis, Instituto Cepa/ SC. $80 \mathrm{p}$.

Bufler G (2001) A simple method to monitor onon bulb dormancy. Acta Horticulturae, 533:129-130.

Cardoso DSCP (2012) Cura artificial de cebola (Allium cepa L.) Dissertação de Mestrado. Universidade Federal de Viçosa, Viçosa. $78 \mathrm{p}$.

Catsky J (1974) Water content. In: Slavik B (Ed.) Methods of studying plant water relations. Berlin, Springer-Verlag. p.121131

Finger FL \& Casali VWD (2002) Colheita, cura e armazenamento da cebola. Informe Agropecuário, 23:93-98.

Grangeiro LC, Souza JO, Aroucha EMM, Nunes GHS \& Santos GM (2008) Características qualitativas de genótipos de cebola. Ciência e Agrotecnologia, 32:1087-1091.

IBGE - Instituto Brasileiro de Geografia e Estatística (2015) Levantamento sistemático de produção agrícola. Disponível em: <http://www.ibge.gov.br/home/estatistica/indicadores/ agropecuaria/lspa>. Acessado em: 21 de agosto de 2015.

Little A (1975) Off on a tangent. Journal of Food Science, 40:410411 .

Maia MCC, Pedrosa JF, Torres filho J, Negreiros MZ de \& Bezerra Neto F (2000) Características de qualidade de cebola múltipla durante armazenamento sob condição ambiental não controlada. Horticultura Brasileira, 18:61-64.
Matos AT (1987) Cura e armazenamento de cebola com utilização de ventilação forçada-Armazém modelo EMPASC. Florianópolis, EMPASC. 12p. (Circular, 113)

Mcguire RG (1992) Reporting of objective color measurements. HortScience, 27:1254-1255.

Miguel ACA, Durigan JF, Bianco MS \& Fugita FY (2005) Influência do estádio de maturação na colheita, sobre a qualidade da cebola 'Superex'. In: XLV Congresso Brasileiro de Olericutura / XV Congresso Brasileiro de Floricultura e Plantas Ornamentais / II Congresso Brasileiro de Cultura de Tecidos de Plantas, Fortaleza. Anais, Horticultura Brasileira. p.437-437.

Muller JJV (1982) Índice visual de dormência - uma proposta. In: XXII Congresso Brasileiro de Olericultura, Vitória. Anais, Secretaria de Estado de Agricultura / Sociedade de Olericultura do Brasil. p.134-134.

Pereira AM, Pimentel DSC, Ferreira APS, Finger FL \& Puiatti M (2012) Avaliação de diferentes métodos de cura artificial de cebola. Horticultura Brasileira, 30:7148-7154.

Santos RR (2007) Análises de sistemas de secagem de café utilizando-se bomba de calor e gás liquefeito de petróleo - GLP. Dissertação de Mestrado. Universidade Federal de Viçosa, Viçosa. $135 \mathrm{p}$.

Schmidt EL, Klocker K, Flacke N \& Steimle F (1998) Applying the transcritical $\mathrm{CO} 2$ process to a drying heat pump. International Journal Refrigeration, 21:202-211.

Souza SO, Silva FC, Finger FL, Casali VWD \& Cecon PR (2010) Qualidade da cebola influenciada pelo estádio de maturação da planta na colheita. Revista Ceres, 57:716-720.

Strommen I, Eikevik TM, Alves filho O, Syverud K, Jonassen O \& Low IE (2002) Temperature drying with heat pumps new generations of high quality dried products. $13^{\text {th }}$ International drying symposium, Beijing. Anais, Taylor \& Francis. p.237245 .

Thompson AK (1998) Controlled atmosphere storage of fruits and vegetables. Wallingford, CAB. 278p.

Weatherley PE (1950) Studies in the water relations of the cotton plant. I. The field measurement of water deficits in leaves. New Phytologist, 49:81-97.

Yokomizo Y, Draetta IS, Costa RB \& Garcia JL (1977) Composição química de diferentes variedades de cebola (Allium cepa L.) e sua caracterização. Coletânea do Instituto de Tecnologia de Alimentos, 8:501-517.

Rev. Ceres, Viçosa, v. 63, n.6, p. 822-828, nov/dez, 2016 